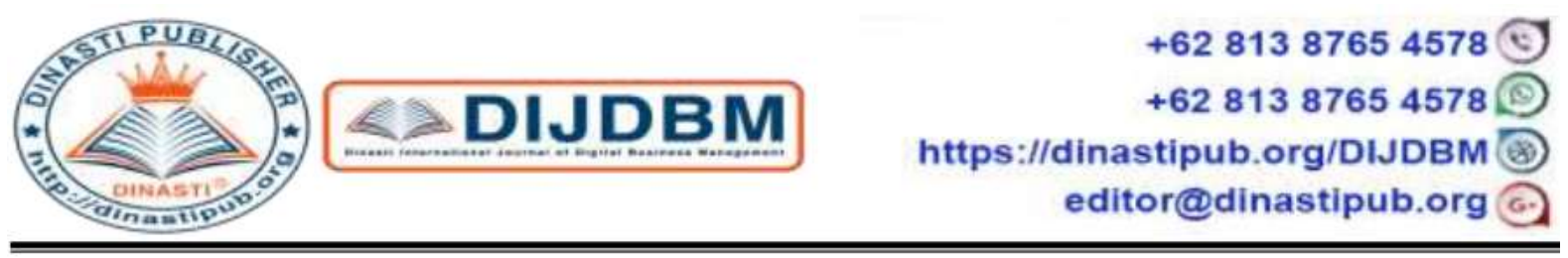

\title{
OPTIMAL PORTFOLIO ANALYSIS OF IDX-30 AND LQ-45 PORTFOLIO WITH THE CAPM METHOD OF THE INDONESIA STOCK EXCHANGE
}

Nur Sarva Jayana ${ }^{1)}$, Pardomuan Sihombing ${ }^{2)}$

${ }^{1,2)}$ Postgraduate Masters in Management, Mercubuana University, Jakarta, Indonesia

ARTICLE INFORMATION

Received: Date Month Year

Revised: Date Month Year

Issued: Date Month Year

(filled in by Editor)

Corresponding author: first author E-mail:

nursarvajayana@gmail.com;

pardomuanssihombing@yahoo.com

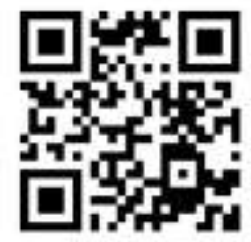

DOI:10.31933/DIJDBM
Abstract: The research objective of this portfolio is to analyze the optimal portfolio IDX-30 and its portfolio of LQ-45 with CAPM method in IDX. This research uses descriptive quantitative method. IDX-30 and LQ45 in the Stock Exchange of the period January 2013 December 2018 the population in the study. A Purposive sampling technique used in determining the sample. Data analysis using Microsoft Excel, from this research are, a). Based on the results of the expected return and risk of IDX-30 and LQ-45, which can be seen from an analysis of individual stocks with a CAPM portfolio. Then the chosen CAPM portfolio, because it produces a good return and minimal risk. And the highest shares of IDX-30 and LQ-45 are TLKM. with the IDX-P 13 return result of 6.5809 and a risk of $7.14 \%$. and LQ- $45 \mathrm{P}_{20}$ return of 6.5764 with a risk of $7.89 \% . b$ ). Optimal portfolios formed using CAPM provide better investment returns than individual shares, because CAPM offers a higher expected return and minimum risk than individual shares. While the optimal portfolio performance of IDX-30 shares evaluated using CAPM is better than the optimal portfolio performance of LQ- 45 shares.

Keywords: IDX-30, LQ-45, Optimal Portfolio, CAPM.

\section{INTRODUCTION}

Portfolios can be the right choice in investing for investors because of the portfolio easily shaped to fit the desired investment characteristics and objectives to be achieved. An efficient portfolio, a portfolio that offers the lowest risk to the level of a certain return, or offering the greatest return rate with certain risks. The assumptions inherent in the portfolio efficiently is all investors dislike risk (risk averse), while assuming the optimal portfolio is selected portfolio of an investor of the many options that exist on the set of efficient portfolios.

Determination model portfolios that emphasize investment risk and return relationship is a model of Markowitz. This model can overcome the disadvantages of random diversification. The assumption that increasing the number of stocks in the portfolio will continually provide 
greater benefits, in contrast to Markowitz model. To predict the expected stock returns, can be used CAPM. This method is a model of balance gives precise predictions about the relationship between the risk of an asset with the expected return, determine the price of an asset and CAPM as a basis for determining a group of stocks that can be selected as a location for investment.

Index of shares listed on stock exchanges works best is the category LQ-45 \& IDX-30, because it is a collection of preferred shares that meet certain criteria. That falls into the criteria LQ-45 stock index and the IDX-30 are stocks that meet the criteria for high rankings on the total transaction, the transaction value, and the frequency of transactions.

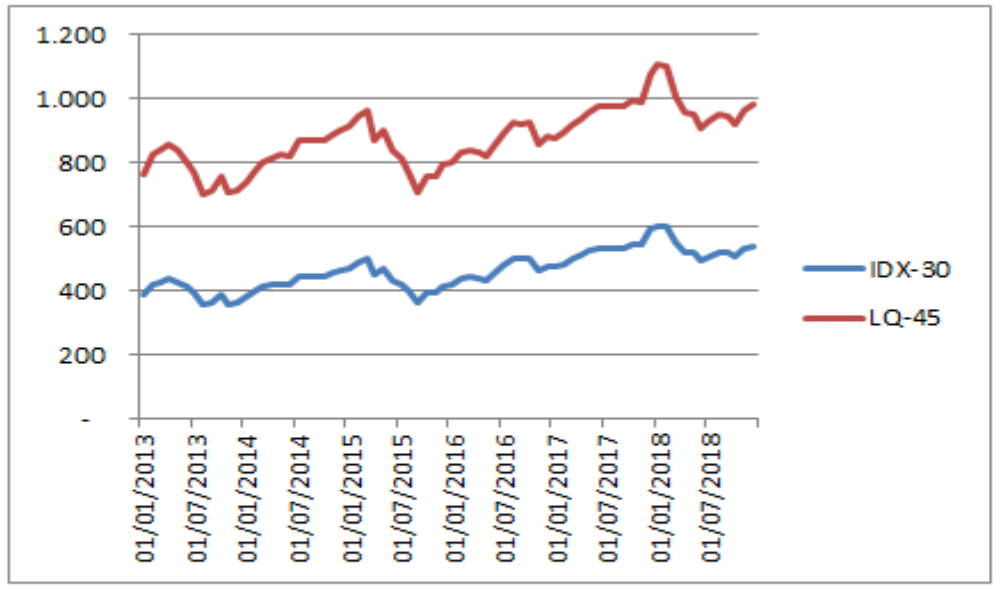

Figure 1. IDX30 Stock Price and LQ-45 Index

Source: www.bloomberg.com (2019)

A share price condition in Figure 1 shows that in the span of time from 2013 to 2018 the increase in the stock price LQ-45 is greater than 875 percent increase in stock prices IDX-30 amounted to 462 percent. We also see that the highest point LQ45 stock price and the IDX-30 occurred in 2018 which LQ45 stock price reached in 1132 and the share price IDX-30 reached 621. Meanwhile, the market price of the lowest point LQ45 and IDX-30 occurred in 2013 where prices LQ-45 reached 652 and IDX-30 stock price reached 333.

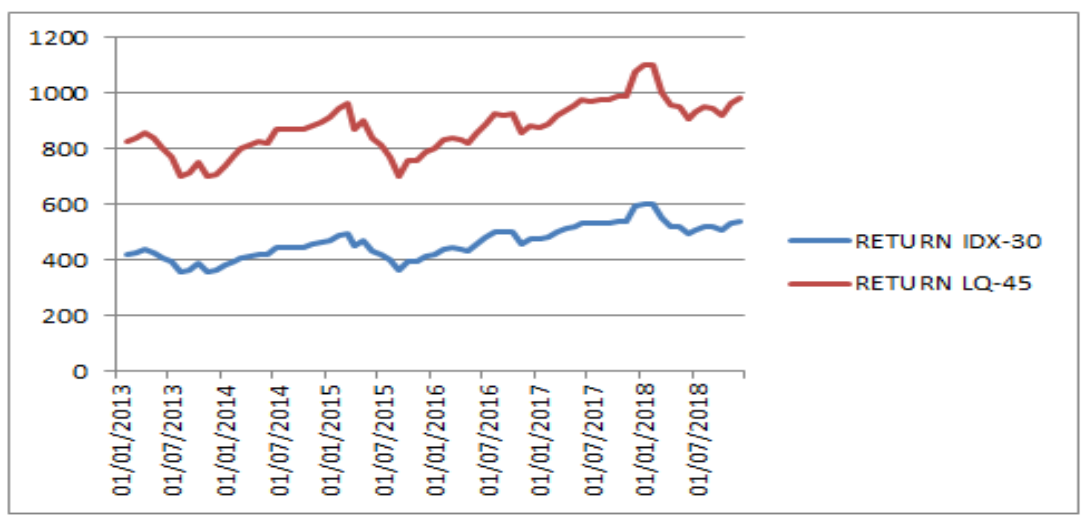

Figure 2 IDX-30 Return and LQ-45 Index

Source: www.bloomberg.com (2019)

In the calculation of the percentage return per year from 2013 through 2018 can be seen in Figure 2 that occur fluctuate up and down return to the LQ-45 and IDX-30. where stocks that declined in 2013 LQ-45 produces 651 percent return, the same thing happened on the IDX- 
30, where it can be seen that in 2013 the return IDX-30 down to 332 percent. Meanwhile, shares of which arose in 2018 LQ-45 generates return in 1131 percent and IDX-30 arose in 2018 with a return of 620 percent. From this data it can be seen that in investing there is uncertainty, investors cannot know with certainty the results obtained from its investments. Investment is a way that can be used to increase the value of assets in the future, wherein the level of investment options have varying risk and return. Investing in the stock market has a high profit potential, but so is the risk.

\section{LITERATURE REVIEW}

\section{Portfolio theory}

According to Hartono (2015) the portfolio can be defined as a combination or a combination of assets. Assets can be construed as investment, financial securities such as deposits, property or real estate, bonds, stocks, and other forms of participation. In the business world, almost all of the owners of capital have a risk-averse attitude which means it does not want a risk that resulted in a loss or reduction in the value of investments.

The theory of Markowitz uses some statistical measurement basis for developing a portfolio plan, including the expected return, standard deviation of both securities and portfolio, and the correlation between the returns "Portfolio Theory Markowitz is based on the approach of the mean (average) and variance (variance), where the mean a measure of the rate of return and the variance is a measure of the level of risk (Sukarno, 2007)

\section{Return portfolio}

Return the realization of the portfolio (portfolio Tirrenus in return) is the weighted average of the return realization of each single securities in the portfolio (Hartono, 2015). Meanwhile, the expected return of the portfolio (portfolio expected return) is a weighted average of the return-return expectations of each single securities in the portfolio (Hartono, 2015).

\section{Portfolio risk}

Risk can be considered as a possibility of loss or destruction. Risk may cause harm if not anticipated and not managed properly. Portfolio risk is a variant return securities that make up the portfolio (Hartono 2015). Unlike a return of the portfolio is a weighted average of all single security risk. Portfolio risk may be smaller than the average risk weighted single securities respectively.

\section{Capital Asset Pricing Model (CAPM)}

Capital asset pricing model or (CAPM) is a theory that explains how the asset price formed in the market. This is an expansion of Markowitz's portfolio theory and made by William Sharpe (1965), and further developed by Lintner (1965) and Jan Mosin (1963). CAPM provides a framework to determine the balance of expected return for a risky asset. It uses the results of the theory of capital markets to draw correlations between expected return and the risks of systematic asset / or portfolios of individual securities (Sihombing, 2014).

\section{LQ-45}

According Darmadji and Fakhruddin (2011) LQ 45 is the common stock of a company that has a high reputation, have a stable income, and consistent in paying dividends. Although it may not all stocks are the stock index in the Indonesia Stock Exchange could not put it in the category of 45 . But for the analyzer LQ LQ 45 can make the footing stock index in the Indonesia Stock Exchange as supporting its decision.

\section{FRAMEWORK}




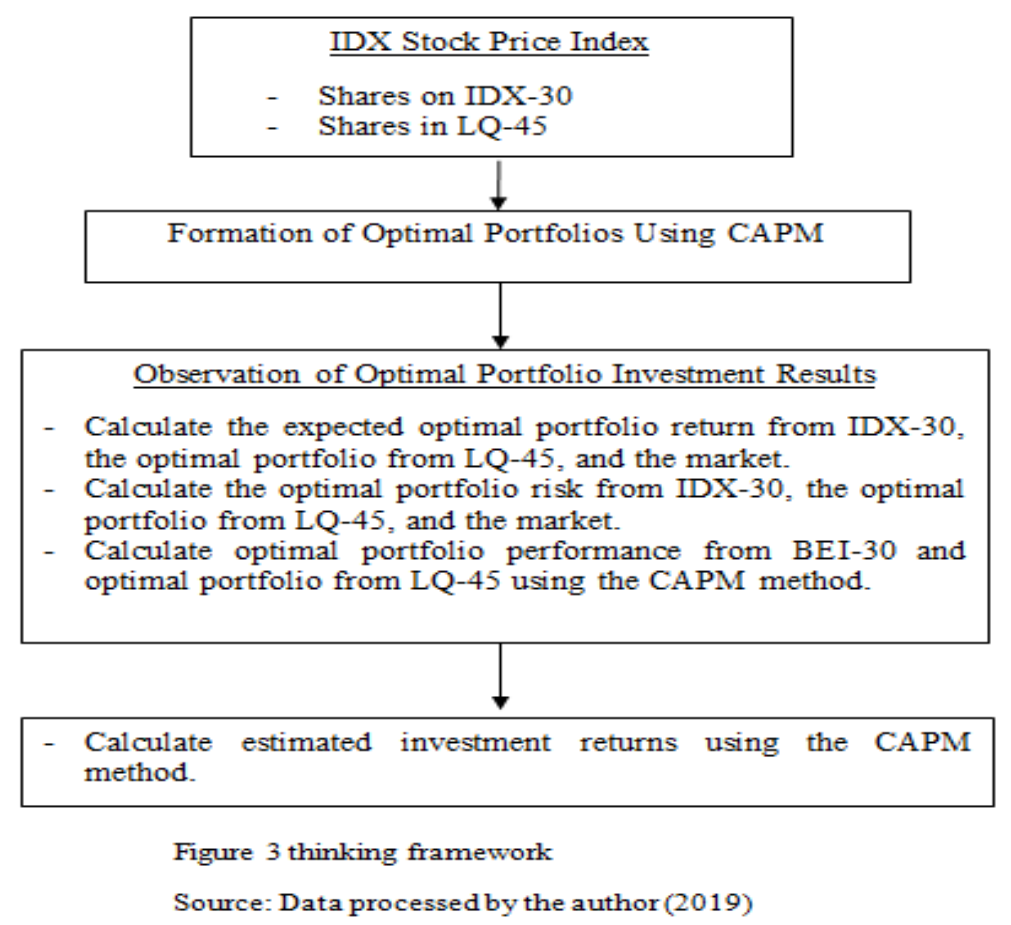

\section{RESEARCH METHODS}

\section{Research design}

In this study using quantitative descriptive research method, the data used is secondary data. Data used in the study, namely stock prices LQ 45 stock index in the Indonesia Stock Exchange (IDX) in the observation period from January 2013 - December 2018 was the closing stock price data monthly closing price as the observation period and the risk free rate.

\section{Population and purposive sampling method}

The population of this research in the form of shares in IDX shares belonging to the IDX-30 \& LQ-45. The population in this study is a stock IDX-30 \& LQ-45 contained in the Stock Exchange of the period January 2013 - December 2018.

The study sample consisted of 30 stocks listed on the IDX-30 and 45 shares listed on LQ 45 in Indonesia Stock Exchange (IDX) is determined by purposive sampling method.

\section{Data Analysis Techniques}

Methods of data analysis were performed by using CAPM to determine the optimal portfolio and optimal portfolio performance, while appliance calculations are performed using Excel. Furthermore, the expected return generated optimal portfolio IDX-30 will be compared with the expected return of LQ-45 index and the expected return of Indonesia Composite Index (ICI).

\section{Individual Performance Shares}

Stock return

$$
R_{i}=\frac{P_{1}-P_{0}}{P_{0}}
$$

\section{Market return}

$$
R_{m}=\frac{I H S G_{1}-I H S G_{t-1}}{I H S G_{t-1}}
$$

\section{Expected return}




$$
\mathrm{E}(\mathrm{Rx})=\frac{\sum \mathrm{Rx}}{\mathrm{n}-1} \quad \mathrm{R}_{\mathrm{i}}=\frac{\mathrm{P}_{1}-\mathrm{P}_{0}}{\mathrm{P}_{0}} \times 100 \%
$$

Variance Shares

$$
\sigma_{1}^{2}=\sum_{t=1}^{n} \frac{\left(R_{j t}-\bar{R} J\right)^{2}}{(n-1)}
$$

Standard Deviation $(\sigma)$ Stock return

$$
\sigma=\sqrt{\frac{\sum\left[R_{x}-E\left(R_{x}\right)^{2}\right]}{n-1}}
$$

Standard Deviation $(\sigma \mathrm{m})$ Market return

$$
\sigma \mathrm{m}=\sqrt{\mathrm{V} \operatorname{ar}(\mathrm{Rm})}
$$

Covariance (cov)

$$
\operatorname{Cov}(\mathrm{Rm}, \mathrm{Rj})=\frac{\sum \mathrm{Rm}-\mathrm{E}(\mathrm{Rm}) \mathrm{x}[\mathrm{Rj}-\mathrm{E}(\mathrm{R} \mathrm{j})]}{\mathrm{n}-1}
$$

$\operatorname{Beta}(\beta)$

$$
\beta_{j}=\frac{\operatorname{COV}(j, m)}{\operatorname{VAR}_{m}}
$$

Risk Stocks (Varian Shares)

$$
\sigma_{\mathrm{ei}}^{2}=\beta_{\mathrm{i}}^{2} \sigma_{\mathrm{e} i}^{2}
$$

Correlation $\mathrm{r}(\mathrm{Rm}, \mathrm{Rf})$

$$
r(R m, R f)=\frac{\operatorname{Cov}(R m, R j)}{\sigma R m, \sigma R j}
$$

\section{Required Return $(\mathbf{R j})$}

$$
R j=R f+[E(R m)-R f] \beta
$$

Stock portfolio performance

\section{Return Portfolio}

Pricing equation model of capital assets written as follows:

$$
E\left(R_{i}\right)=R_{f}+\beta_{i}\left(E\left(R_{M}\right)-R_{f}\right)
$$

\section{Portfolio risk}

$$
\sigma_{\mathrm{p}}^{2}=\left[\beta_{\mathrm{p}}^{2} \times \sigma_{\mathrm{m}}^{2}\right]+\left[\sum_{\mathrm{i}=1}^{\mathrm{n}} \mathrm{x}_{1}^{2} \cdot \sigma_{\mathrm{e} i}^{2}\right]
$$

Expected Rate of Return (Return rate expected) 


$$
\mathrm{E}\left(\mathrm{R}_{\mathrm{p}}\right)=\mathrm{X}_{\mathrm{A}} \mathrm{E}\left(\mathrm{R}_{\mathrm{A}}\right)+\mathrm{X}_{\mathrm{B}} \mathrm{E}\left(\mathrm{R}_{\mathrm{B}}\right)+\mathrm{X}_{\mathrm{C}} \mathrm{E}\left(\mathrm{R}_{\mathrm{C}}\right)+\mathrm{X}_{\mathrm{n}} \mathrm{E}\left(\mathrm{R}_{n}\right), \ldots, \mathrm{X}_{\mathrm{n}} \mathrm{E}\left(\mathrm{R}_{\mathrm{n}}\right)
$$

\section{Standard Deviation, Portfolio Shares}

$$
\begin{aligned}
& \sigma_{P}=\left(\left(X_{A}^{2} \sigma_{A}^{2}+X_{B}^{2} \sigma_{B}^{2}+X_{C}^{2} \sigma_{C}^{2}+, \ldots \ldots, X_{n}^{2} \sigma_{n}^{2}+\right.\right. \\
& \left.n\left(X_{A} \cdot X_{B} \cdot X_{C} \ldots X_{n} \cdot r_{A B C},{ }_{n} \cdot \sigma_{A} \sigma_{B} \sigma_{C}, \ldots \ldots, \sigma_{n}\right)\right)^{1 / 2}
\end{aligned}
$$

\section{FINDINGS AND DISCUSSION}

\section{Proportion Shares On Optimal Portfolio IDX-30}

To calculate the return and portfolio risk ADRO, ASII, BBCA, BBNI, BBRI, BMRI, GGRM, INDF, INTP, KLBF, PGN, SMGR, TLKM, UNTR, UNVR, required the calculation of the combination between fifteen shares. All the data in the appendix.

Results alternative combinations of the portfolio of stocks selected fifteen $\mathrm{P}_{2}$ alternative portfolio with an alternative composition formed by the largest stock UNTR 0.27.

\section{Shares Proportion Portfolio Optimal LQ-45}

To calculate the return and portfolio risk ADRO, AKRA, ASII, BBCA, BBNI, BBRI, BMRI, BSDE, GGRM, ICBP, INDF, INTP, JSMR, KLBF, LPKR, MNCN, PGN PTBA, SMGR, TLKM, UNTR, UNVR, required the calculation of the combination between twenty-two stocks. All the data in the appendix.

The results of the portfolio of alternative combinations of the twenty-two stocks have a portfolio of alternative $\mathrm{P}_{3}$ with the largest alternative composition formed UNTR shares of 0.1 .

\section{Optimal portfolio of individual stocks in a portfolio CAPM}

The formation of this optimal portfolio using a mathematical analysis process with the method used, the model of capital asset pricing models. The use of capital asset pricing models to determine the optimal portfolio models, based on a comparison of Ri and $\mathrm{E}(\mathrm{Ri})$, if $\mathrm{Ri}>\mathrm{E}(\mathrm{Ri})$ then the shares are classified as undervalued and $\mathrm{Ri}<\mathrm{E}(\mathrm{Ri})$ called overvalued. If the shares of IDX-30 and LQ-45 are classified as undervalued, investors or financiers is should buy shares of IDX-30 and the LQ-45 index. If $\mathrm{Ri}>\mathrm{E}(\mathrm{Ri})$, then the shares are put into optimal portfolio candidates. Whereas if $\mathrm{Ri}<\mathrm{E}$ ( $\mathrm{Ri}$ ), the shares were not included in the candidate optimal portfolio of stocks.

Optimal portfolio expected return of individual stocks to a portfolio CAPM IDX-30 
Table 1. Optimal portfolio expected return of individual stocks to a portfolio CAPM IDX-30

\begin{tabular}{cccc}
\hline \multirow{2}{*}{$\begin{array}{c}\text { DX-30 Portfolio } \\
\text { Comparison }\end{array}$} & \multicolumn{3}{c}{ January 2013-December 2018 } \\
\cline { 2 - 3 } & \multicolumn{2}{c}{ Erp } & Information \\
\cline { 2 - 3 } & 0,0024 & 6,5728 & Undervalued \\
\hline$P_{1}$ & 0,0036 & 6,5747 & Undervalued \\
$\mathrm{P}_{2}$ & 0,0155 & 6,5731 & Undervalued \\
$\mathrm{P}_{3}$ & 0,0152 & 6,5620 & Undervalued \\
$\mathrm{P}_{4}$ & 0,0149 & 6,5653 & Undervalued \\
$\mathrm{P}_{5}$ & 0,0091 & 6,5610 & Undervalued \\
$\mathrm{P}_{6}$ & 0,0091 & 6,5538 & Undervalued \\
$\mathrm{P}_{7}$ & 0,0052 & 6,5572 & Undervalued \\
$\mathrm{P}_{8}$ & 0,0025 & 6,5734 & Undervalued \\
$\mathrm{P}_{9}$ & 0,0068 & 6,5636 & Undervalued \\
$\mathrm{P}_{10}$ & $-0,0041$ & 6,5701 & Undervalued \\
$\mathrm{P}_{11}$ & $-0,0007$ & 6,5694 & Undervalued \\
$\mathrm{P}_{12}$ & 0,0111 & 6,5809 & Undervalued \\
$\mathrm{P}_{13}$ & 0,0072 & 6,5705 & Undervalued \\
$\mathrm{P}_{14}$ & 0,0118 & 6,5706 & Undervalued \\
$\mathrm{P}_{15}$ & Stock & CAPM & \\
Source: The author's data processingresults, Microsoft Excel 2019
\end{tabular}

From the calculation table 1, there are factors that need to be noticed by performing classification $\mathrm{Ri}>\mathrm{E}$ ( $\mathrm{Ri}$ ). Judging from the classification of the entire 15 stock IDX-30, has the result undervalued. Since these shares offer a higher expected return of the assets in the same risk class so they are becoming more attractive. Buying pressure for such assets will push up the price until the assets reach the correct price.

Optimal portfolio expected return of individual stocks to a portfolio CAPM LQ-45

Table 2. Optimal portfolio expected return of individual stocks to a portfolio CAPM LQ45

\begin{tabular}{|c|c|c|c|}
\hline \multirow{3}{*}{$\begin{array}{l}\text { Portolio } \\
\text { Companimon } \\
\text { LQ-45 }\end{array}$} & \multicolumn{3}{|c|}{ Jammary 2013 -December $201 \mathrm{~s}$} \\
\hline & \multicolumn{2}{|l|}{ Exp } & \multirow{2}{*}{ Informadion } \\
\hline & Individual Stock & CAPMI & \\
\hline P. & 0,0024 & 6,5619 & Undervalued \\
\hline$P_{3}$ & 0,0050 & 6,5003 & Undervalued \\
\hline P. & 0,0036 & 6,5676 & Undervalued \\
\hline$P_{+}$ & 0,0155 & 6,5609 & Undervalued. \\
\hline P, & 0,0152 & 6,5673 & Undervalued \\
\hline P. & 0,0149 & 6,5745 & Undervalued \\
\hline P, & 0,0091 & 6.5755 & Undervalued \\
\hline P. & 0,0027 & 6,5720 & Undervalued \\
\hline $\mathbf{P}$ & 0,0091 & 0,5727 & Undervalued \\
\hline $\mathbf{P}_{n}$ & 0,0157 & 6,5581 & Undervalued \\
\hline $\mathbf{P}_{\text {., }}$ & 0.0052 & 6,5660 & Undervalued \\
\hline $\mathbf{P}_{t=}$ & 0.0025 & 6,5612 & Undervalued \\
\hline$P_{3}$. & $-0,0010$ & 0.5040 & Undervalued \\
\hline$P_{\text {: }}$ & 0,0068 & 6.5609 & Undervalued \\
\hline Pin & $-0,0138$ & $6,57.42$ & Undervaluod \\
\hline Pun & -0.0092 & 0.5086 & Undervalued \\
\hline$P_{1:}$ & $0,00-11$ & 6,5624 & Undervalued \\
\hline$P_{1=}$ & 0,0129 & 6,5708 & Undervalued \\
\hline$P_{n s}$ & -0.0007 & 0.5057 & Undervatued \\
\hline $\mathbf{P}_{2 n}$ & 0,0111 & 6,5764 & Und-rvalued \\
\hline$P_{2,}$ & 0,0072 & 0,5549 & Undervilued. \\
\hline$P_{x x}$ & 0.0118 & 6.5598 & Undervalued \\
\hline
\end{tabular}

Seen from Table 2, all the LQ-45 produces undervalued because returns are expected to have a value below the value of individual stock returns. So the conclusion of CAPM calculation, the 22 stock price is quite cheap, because the return is greater than the expected return. 
Comparison Portfolio IDX-30 expected return and risk of individual stocks and CAPM.

Table 3. Comparison of Portfolio IDX-30 expected return and risk of individual stocks and CAPM.

\begin{tabular}{|c|c|c|c|c|}
\hline \multirow{3}{*}{$\begin{array}{l}\text { mX-30 } \\
\text { Portolio } \\
\text { Comparison }\end{array}$} & \multicolumn{4}{|c|}{ January 2013 -December 2018} \\
\hline & \multicolumn{2}{|c|}{ Erp } & \multicolumn{2}{|l|}{ op } \\
\hline & $\begin{array}{c}\text { Individual } \\
\text { Stock }\end{array}$ & CAPM & $\begin{array}{c}\text { Individual } \\
\text { Stoek }\end{array}$ & CAPM \\
\hline $\mathbf{P}_{\mathbf{r}}$ & 0,0024 & 6,5728 & $8,01 \%$ & $8,01 \%$ \\
\hline $\mathbf{P}_{2}$ & 0,0036 & 6,5747 & $7,61 \%$ & $7,61 \%$ \\
\hline $\mathbf{P}_{3}$ & 0,0155 & 6,5731 & $7,74 \%$ & $7,74 \%$ \\
\hline P. & 0,0152 & 6,5620 & $7.84 \%$ & $7,8.4 \%$ \\
\hline Ps & 0,0149 & 6,5653 & $8,58 \%$ & $8,58 \%$ \\
\hline P. & 0,0091 & 6,5610 & $6,92 \%$ & $6,92 \%$ \\
\hline $\mathbf{P}_{3}$ & 0,0091 & 6,5538 & $8,06 \%$ & $8,06 \%$ \\
\hline P. & 0,0052 & 6,5572 & $7,48 \%$ & $7,48 \%$ \\
\hline $\mathbf{P}_{4}$ & 0,0025 & 6,5734 & $7,37 \%$ & $7,37 \%$ \\
\hline Pre & 0,0068 & 6,5636 & $7,21 \%$ & $7,21 \%$ \\
\hline P.. & $-0,0041$ & $6,5>01$ & $8,18 \%$ & $8,18 \%$ \\
\hline$P_{12}$ & $-0,0007$ & 6,5694 & $7,58 \%$ & $7,58 \%$ \\
\hline$P_{13}$ & 0,0111 & 6,5809 & $7,14 \%$ & $7,14 \%$ \\
\hline$P_{14}$ & 0,0072 & 6,5705 & $7,29 \% 6$ & $7,29 \%$ \\
\hline$P_{i s}$ & 0,0118 & 6,5706 & $9,24 \%$ & $9,24 \%$ \\
\hline Total & 0,1096 & 98,5184 & $116 \%$ & $116 \%$ \\
\hline Rata-rata & 0.0073 & 65679 & 0.0775 & 0.0775 \\
\hline
\end{tabular}

In Table 3. Comparison of IDX-30 Portfolios expected return and risk of individual stocks and CAPM in accordance with portfolio objectives seen the highest return and minimum or certain risk, then the chosen CAPM portfolio because there are several individual stocks that produce negative and average returns the return calculation is below $5 \%$ or 0.0073 . While the average CAPM return is 6.5679 and the highest share is TLKM $\mathrm{P}_{13}$ return of 6.5809 and a risk of $7.14 \%$.

\section{Portfolio Comparison LQ-45 expected return and risk of individual stocks and CAPM}

Table 4. Comparison of Portfolio LQ-45 expected return and risk of individual stocks and CAPM

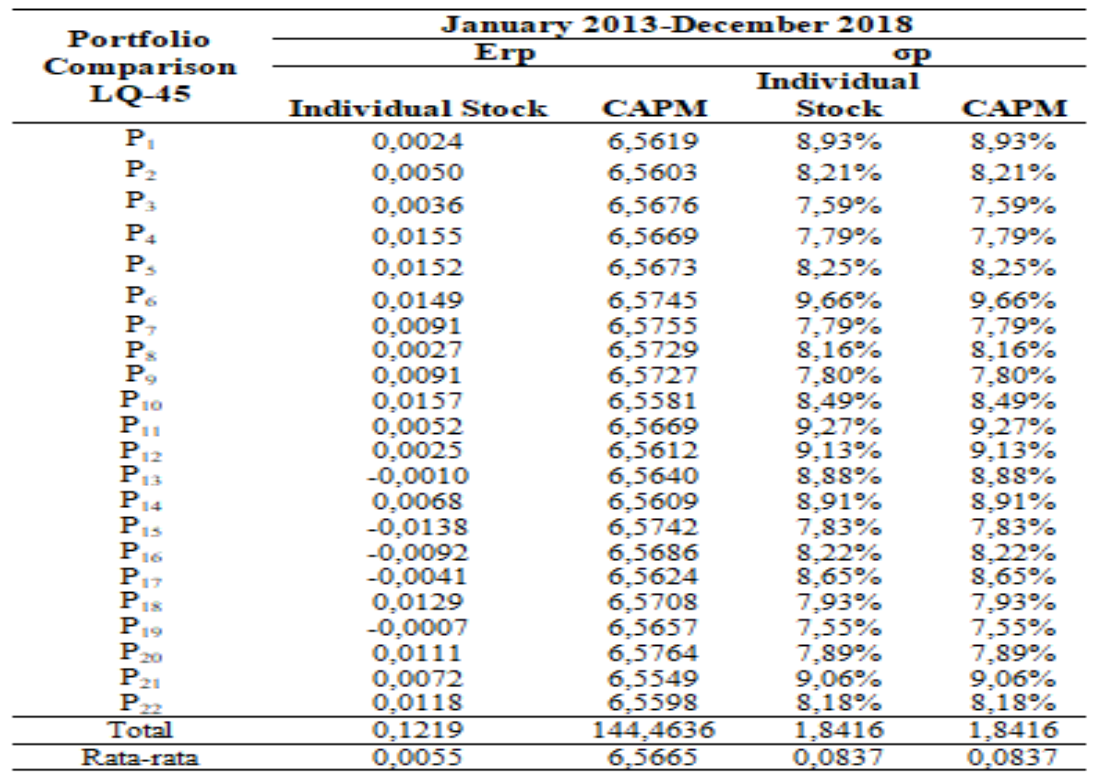

Source: The author's data processing results, Microsoft Excel 2019. 
In Table 4. Comparison of LQ-45 Portfolios expected return and risk of individual shares and CAPM that are in accordance with the objectives of the portfolio are considered minimum return and minimum risk, then the chosen CAPM portfolio because there are several individual stocks that produce negative returns and average return calculation under $5 \%$ or 0.0055 . While the average return of CAPM is 6.5665 and the highest share is TLKM $\mathrm{P}_{20}$ return of 6.5764 and a risk of $7.89 \%$.

Based on the comparison of portfolio that has been done, of 15 shares of IDX-30 and 22 LQ-45 sample, stock index the best use of capital asset pricing models of IDX-30 in view of the average expected return and risk CAPM. As well, judging from the calculation of the optimal portfolio of individual stocks and shares best CAPM is TLKM because it has highest returns and minimum risk or specific.

\section{CONCLUSION AND SUGGESTION}

Based on the results of the expected return and risk of IDX-30 and LQ-45, which can be seen from an analysis of individual stocks with a CAPM portfolio. Then the chosen CAPM portfolio, because it produces a good return and minimal risk. And the highest shares of IDX-30 and LQ-45 are TLKM. with the IDX-P $\mathrm{P}_{13}$ return result of 6.5809 and a risk of $7.14 \%$. and LQ-45 $\mathrm{P}_{20}$ return of 6.5764 with a risk of $7.89 \%$

Optimal portfolios formed using CAPM provide better investment returns than individual shares, because CAPM offers a higher expected return and minimum risk than individual shares. While the optimal portfolio performance of IDX-30 shares evaluated using CAPM is better than the optimal portfolio performance of LQ-45 shares.

Portfolio generated in this study is a portfolio done by using historical data, so it cannot promise similar results when using different samples and different study period.

Investors should choose stocks that are more varied in various industries portfolio and subsections listed on the Indonesia Stock Exchange in order to be formed can be optimized to generate returns and minimize risk.

Investors can use a method other than the capital asset pricing model (CAPM) to analyze the value of the securities that will be an asset to their investment. Because the model of capital asset pricing model (CAPM) correlates only securities in any form either systematic risk or who unsystematic. In addition to the capital asset pricing puts investors on the assumption of risk-free assets that actually became one so important factor in the investment world today investor expectations equilibrium conditions, as well as the market balances that facilitate investors in the analysis.

\section{REFERENCE}

Darmadji, T., and Fakhruddin, HM (2011). Capital Market in Indonesia: Approach FAQ (Issue 3). Jakarta: Four Salemba.

Hartono, Jogiyanto. (2015). Portfolio Theory and Investment Analysis tenth edition, Yogyakarta: Yogyakarta BPFE.

Jayana, Nur Sarva. (2018). Selection Of Leanding Sectors Share Portfolio Using Capital Asset Pricing Model (CAPM) In Indonesia Stock Exchange (IDX) Period February 2012 - March 2016. IJISRT, Vol. 3, No 2456-2165.

Markowitz, Harry M, (1999). "The Early History of Portfolio Theory: 1600-1960", Financial Analysis Journal, p.5-16.

Sharpe, William, (1963), A Simplified Model for Portfolio Analysis, Management Science, Vol.9, No. 2, pp. 277-293. 
Sharpe, William F. (1995). The Journal of Portfolio Management at Stanford University. 425-442.

Sharpe, WilliamF., Alexander, Gordon J., Jeffery V. Bailey (2005). Investment, Prentince Hall. Inc., New Jersey

Sihombing, Pardomuan. (2014). Determinants Government Bond Yield Curve (SUN). Bogor: Dissertation IPB.

Sukarno, Mokhamad. (2007). "Analysis of Optimal Equity Portfolio Formation Method Using Single Index in Jakarta Stock Exchange". Thesis. Management Program at Diponegoro. Semarang.

Tandelilin, Eduardus. (2010). Investment Analysis and Portfolio Management. First Edition, First Printing, Yogyakarta: Yogyakarta BPFE.

www.bloomberg.com

www.idx.co.id 